\title{
Improved $\mathrm{Pt} / \mathrm{CeO}_{2}$ Electrocatalysts for Ethanol Electro- oxidation
}

\author{
Guilherme L. Cordeiro ${ }^{1}$, Elaine F. de Camargo ${ }^{1}$, Monique C. L. Santos ${ }^{2}$, Conrado V. Pereira ${ }^{2}$, \\ Valter Ussui ${ }^{1}$, Nelson B. de Lima ${ }^{1}$, Almir O. Neto ${ }^{2, *}$, Dolores R. R. Lazar ${ }^{1}$ \\ ${ }^{1}$ Materials Science and Technology Center \\ ${ }^{2}$ Fuel Cells and Hydrogen Center, Energy and Nuclear Research Institute (IPEN-CNEN/SP), Lineu \\ Prestes Avenue, 2242 - Zip Code: 05508-000 - São Paulo, Brazil \\ *E-mail: aolivei@ipen.br
}

doi: $10.20964 / 2018.07 .58$

Received: 8 March 2018 / Accepted: 28 April 2018 / Published: 5 June 2018

\begin{abstract}
A simple and low-cost approach for the preparation of wide-gap $\left(E_{\mathrm{g}}=3.43 \mathrm{eV}\right)$, fine cerium dioxide crystals $\left(\mathrm{CeO}_{2}, d=8.1 \mathrm{~nm}\right)$, was developed in order to support Pt nanoparticles as electrocatalysts for ethanol oxidation. Cerium oxide powders were prepared by precipitation from cerium chloride solution in ammonia medium and the influence of calcination temperature was evaluated. Platinum nanoparticles were incorporated by a wet chemical reduction of chloroplatinic acid with sodium borohydrate. Compared to a state-of-the-art Pt/C, the nanocomposite exhibited a much higher mass activity $(2.5 \times)$ and significant antipoisoning ability. The promotional effect of the $\mathrm{CeO}_{2}$ nanocrystals was discovered to be affected by heat treatment conditions. Compared to oven-dried samples, calcination allows to (i) an enhanced metal-support interaction between $\mathrm{CeO}_{2}$ and $\mathrm{Pt}$ and (ii) an enhancement of electron transportation to catalyst owing to the shrinkage of $\mathrm{CeO}_{2}$ bandgap, thereby promoting the oxidation of the strongly adsorbed $\mathrm{C}_{\mathbf{x}} \mathrm{H}_{\mathbf{y}}$. Therefore, the $\mathrm{Pt} / \mathrm{CeO}_{2}$ nanocomposite appears to be a promising electrocatalyst for advanced energy conversion.
\end{abstract}

Keywords: $\mathrm{Pt} / \mathrm{CeO}_{2}$ electrocatalysts, semiconductors, crystal growth, bandgap, ethanol oxidation.

\section{FULL TEXT}

(C) 2018 The Authors. Published by ESG (www.electrochemsci.org). This article is an open access article distributed under the terms and conditions of the Creative Commons Attribution license (http://creativecommons.org/licenses/by/4.0/). 